\title{
Effect of exo-polysaccharides producing bacterial inoculation on growth of roots of wheat (Triticum aestivum L.) plants grown in a salt-affected soil
}

\author{
${ }^{1 *}$ M. Ashraf, ${ }^{2}$ S. Hasnain and ${ }^{3} O$. Berge \\ ${ }^{1}$ Nuclear Institute for Agriculture and Biology (NIAB), Faisalabad, Pakistan \\ ${ }^{2}$ Department of Botany, University of the Punjab, Quaid-e-Azam Campus, Pakistan \\ ${ }^{3}$ Laboratoire d'Ecologie Microbienne de la Rhizosphère (LEMiR), Saint Paul lez-Durance, France
}

Received 25 December 2005; $\quad$ revised 15 February 2006; $\quad$ accepted 1 March $2006 \quad$ available online 18 April 2006

\begin{abstract}
Effect of soil salinity on physico-chemical and biological properties renders the salt-affected soils unsuitable for soil microbial processes and growth of the crop plants. Soil aggregation around roots of the plants is a function of the bacterial exo-polysaccharides (EPS), however, such a role of the EPS-producing bacteria in the saline environments has rarely been investigated. Pot experiments were conducted to observe the effects of inoculating six strains of EPS-producing bacteria on growth of primary (seminal) roots and its relationship with saccharides, cations $\left(\mathrm{Ca}^{2+}, \mathrm{Na}^{+}, \mathrm{K}^{+}\right)$contents and mass of rhizosheath soils of roots of the wheat plants grown in a salt-affected soil. A strong positive relationship of RS with different root growth parameters indicated that an integrated influence of various biotic and abiotic RS factors would have controlled and promoted growth of roots of the inoculated wheat plants. The increase in root growth in turn could help inoculated wheat plants to withstand the negative effects of soil salinity through an enhanced soil water uptake, a restricted $\mathrm{Na}^{+}$influx in the plants and the accelerated soil microbial process involved in cycling and availability of the soil nutrients to the plants. It was concluded that inoculation of the EPS-producing would be a valuable tool for amelioration and increasing crop productivity of the salt-affected soils.
\end{abstract}

Key words: EPS-producing bacteria, soil salinity, wheat plants, rhizosheath, root/shoot ratio, $\mathrm{K}^{+} / \mathrm{Na}^{+}$ratio

*Corresponding Author, E-mail:botany_malik@yahoo.com

\section{INTRODUCTION}

Soil salinity is one of the major agricultural problems limiting crop productivity in most of the arid and semi arid regions of the world. A direct effect of soil salinity on physico-chemical and biological properties renders these marginal soils unsuitable for soil microbial processes and growth of the crop plants (Munns, 2002; Rengasamy et al., 2003). Biochemical signals transmitted from roots to the shoot are considered the important factors that confer salt tolerance in plants (Shen, 2001; Munns, 2002). However, significance and role of roots of the plants in improving fertility and crop productivity of the salt-affected soils have mostly been remained unexplored (Munns, 2002). Most of the nutrients and water taken up by plants are passed through the interfacial region, the rhizosheaths (RS); the soil adhered strictly to the roots of the crop plants (McCully and Canny, 1988; Watt et al., 1994). Intimate association of plant roots to the soil in this region not only enables plants to harness nutrients from the soil but it also provides source of $\mathrm{C}$ supply (in the form of root exudates) to the soil microbes that are involved in cycling, mineralization and availability of the soil nutrients to the growing plants (Nannipieri, et al., 2003). After harvesting at maturity, the root portions of the crop plants with attached rhizosheaths are ploughed under the soil that contribute to formation and build up of the soil micro-aggregates (Chenu and Guerif, 1991; Tisdall, 1994), the soil structures indispensable for physico-chemical fabric and fertility of the agricultural soils. Formation of rhizosheaths around roots of the plants is the function of a class of soil saccharides called the exo-polysaccharides (EPS) (Czarnes, et al., 2000). These EPS are synthesized and released in the soil by micro-organisms living in vicinity or associated with roots of the plants. Among these rhizospheric soil microbes, EPS-producing rhizobacteria are considered to be mainly involved in soil aggregation and formation of RSs' around roots of the crop plants 
(Watt, et al., 1993; Czarnes, et al., 2000, Vanhaverbeke, et al. 2003). It could be presumed that increasing the population density of the EPS-producing bacteria in the root zone of the plants grown on the salt-affected soils might help alleviate salt-stress on growth of the crop plants. However, such a role of the EPS-producing bacteria in the saline environments has rarely been investigated and thus the information are quite sketchy. A series of research studies, therefore, was initiated to isolate and identify the EPS-producing bacteria from rhizosphere of wheat and barley plants grown on the salt-affected soils (Ashraf, et al. 1999) and to investigate various aspects of EPS-producing bacterial inoculation on growth of the crop plants in the saline environments with a view to find its practical and biotechnological implications for agriculture industry. In our previous research report (Ashraf, et al. 2004) a restricted uptake of $\mathrm{Na}^{+}$by wheat plants inoculated with the EPS-producing bacterial isolates MAS765 (Aeromonas hydrophila/caviae), MAS17 (Bacillus insolitus), and MAS617, MAS620, MAS820 (Bacillus sp.) grown in a salt-affected soil was observed. Although the restricted influx of $\mathrm{Na}^{+}$in the plants was attributed to a decrease in uncovered root area of the plants, a direct contribution of RS and the EPS-producing bacteria in alleviating salts stress on growth of the plants could not be precluded.

Objectives of this research work were (1) to observe whether or not inoculation of the other EPS-producing bacteria cause a similar effect on $\mathrm{Na}^{+}$uptake by wheat plants (2) to investigate and compare the effect of the inoculation on growth of roots of the plants inoculated with different EPS-producing bacterial isolates and (3) relationship of mass of RS, saccharides, $\mathrm{Ca}^{2+}, \mathrm{Na}^{+}$and $\mathrm{K}^{+}$contents of the RS, roots, and the plant with different root growth parameters of the inoculated wheat plants. The EPS-producing bacterial isolates used in the study were Microbacterium sp. (strain MAS133), Bacillus amyloliquefacian (strains MAS4 and MAS526), B. insolitus (strains MAS10 and MAS26) and Pseudomonas syringae (strain MAS129). The root growth parameters (Atkinson, 2000) included the number of primary (seminal) roots, longest root growth, total seminal root length dry matter yield of the roots and shoot and root/shoot ratio.

This work was conducted in the year 2003 and 2004 at Salinity and Environmental Management Division, Nuclear Institute for Agriculture and Biology (NIAB), Faisalabad, Pakistan.

\section{MATERIALS AND METHODS}

A moderately saline soil was collected from the saltaffected area at Pacca Anna, $30 \mathrm{~km}$ southwest of Faisalabad, Pakistan. Physicochemical characteristics of the air-dried and sieved $(<2 \mathrm{~mm})$ soil were: sand, 56.3\%; silt, 29.2\%; clay, $12.0 \%$; maximum water-holding capacity, 20\%; organic C, 2.9 g/kg; total N, 0.34 g/kg; mineral N, $18.6 \mathrm{mg} / \mathrm{kg}$; $\mathrm{pH}$ (saturation paste), 8.2; electrical conductivity (saturation extract), $8.0 \mathrm{dS} / \mathrm{m}$; sodium absorption ratio, 11.7; and water-soluble $\mathrm{Na}^{+}$, $\mathrm{K}^{+}, \mathrm{Ca}^{2+}, \mathrm{Mg}^{2+}, \mathrm{Cl}^{-}$, and $\mathrm{SO}_{4}{ }^{2-}, 45.7,3.4,11.1,4.2,11.4$, and $22.7 \mathrm{mmol} / \mathrm{kg}$, respectively. The bacteria were isolated from the rhizosphere soil (RS) of wheat grown in a salt-affected soil (Ashraf, et al., 1999). The bacterial genera included: Bacillus amyloliquefaciens (strains MAS4 and MAS526), B. insolitus (strains MAS10 and MAS26), Microbacterium sp. (strain MAS133), and Pseudomonas syringae (strain MAS129). Polysaccharide production by these bacteria was observed by spot plate method on RCV-sucrose medium (modified Weaver's medium, Amellal, et al., 1998) containing 40 $\mathrm{g} / \mathrm{L}$ sucrose and $15 \mathrm{~g} / \mathrm{L} \mathrm{NaCl}$. Tryptic-soy-broth, supplemented with $15 \mathrm{~g} / \mathrm{L} \mathrm{NaCl}$ was used for culturing the EPS bacteria; the population density after a $24 \mathrm{~h}$ incubation at $30^{\circ} \mathrm{C}$ was $10^{9}$ colony-forming units (CFU)/ $\mathrm{mL}$. Bacterial cells from the over-nightly grown cultures were harvested by centrifugation $(16000 \times \mathrm{g}, 10 \mathrm{~min})$, washed twice with and suspended in sterile distilled water (SDW) for inoculation. Soils were also sprayed with the respective bacterial suspension (final bacterial count, $10^{8} \mathrm{CFU} / \mathrm{g}$ soil) and mixed thoroughly. The inoculated soil was then distributed in plastic pots (250 g soil/pot). Soil sprayed with SDW served as control. Seeds of wheat (Triticum aestivum L. CV Inqalab-91) were surface sterilized in $2 \% \mathrm{Ca}(\mathrm{OCl})_{2}$ for $2 \mathrm{~h}$, rinsed in SDW, soaked in $11 \% \mathrm{H}_{2} \mathrm{O}_{2}$ for $20 \mathrm{~min}$, and washed thoroughly with SDW. The seeds were germinated in sterile Petri plates using a drop of water. Upon germination the sterility of seedlings was checked by overnight incubation at $30^{\circ} \mathrm{C}$ in liquid broth. Roots of five-day old seedlings were soaked for $2 \mathrm{~h}$ in an actively growing bacterial culture $\left(10^{9} \mathrm{CFU} \mathrm{m} / \mathrm{L}\right)$ and transplanted (4 seedlings/pot) into the respective inoculated soil. An average population density of the EPS-producing bacterial isolates at the time of transplanting was found to be $\cong 10^{6} \mathrm{CFU} / \mathrm{g}$ root dry weights. For control, seedlings soaked in SDW were transplanted into un-inoculated soil. Plants were grown in a growth chamber with day/night temperatures of 15 
Effect of exo-polysaccharides...

Table 1: Number of primary roots (Nos.), longest vertical root growth (V), total root length $(\mathrm{T})$, numbers of leaves, leaf area (LA), root/shoot ratio (RT/SHT) and dry matter (DM) yield plant ${ }^{-1}$ of roots, shoot, and the wheat (T. aestivum L.) plants un-inoculated and inoculated with EPS-producing bacteria

\begin{tabular}{|c|c|c|c|c|c|c|c|c|c|}
\hline \multirow[b]{2}{*}{ Bacterial strains } & \multicolumn{3}{|c|}{ Root length } & \multirow[b]{2}{*}{$\begin{array}{l}\mathrm{DM} \\
(\mathrm{mg})\end{array}$} & \multicolumn{2}{|c|}{ Shoot } & \multicolumn{3}{|c|}{ Plant } \\
\hline & Nos. & $\begin{array}{c}(\mathrm{cm}) \\
\mathrm{V}\end{array}$ & $\mathrm{T}$ & & $\begin{array}{l}\text { Leaf } \\
\text { (Nos.) }\end{array}$ & $\begin{array}{l}\mathrm{LA} \\
\left(\mathrm{cm}^{2}\right)\end{array}$ & $\begin{array}{l}\text { DM } \\
(\mathrm{mg})\end{array}$ & $\begin{array}{l}\text { DM } \\
(\mathrm{mg})\end{array}$ & $\begin{array}{c}\text { RT/S } \\
\text { HT }\end{array}$ \\
\hline Control & $5.0 b^{*}$ & $5.5 f$ & $14.1 d$ & $5.1 \mathrm{~cd}$ & $2.5 b$ & $3.17 \mathrm{e}$ & $12.4 \mathrm{~d}$ & $17.5 \mathrm{~d}$ & $0.41 c$ \\
\hline $\begin{array}{l}\text { B. amyloliquefacian } \\
\text { (MAS4) }\end{array}$ & $\begin{array}{c}6.7 \mathrm{a} \\
(34)^{* *}\end{array}$ & $\begin{array}{c}7.8 \mathrm{c} \\
(41.8)\end{array}$ & $\begin{array}{c}28.6 c \\
(102.8)\end{array}$ & $\begin{array}{c}9.0 \mathrm{c} \\
(76.5)\end{array}$ & $\begin{array}{l}3.0 \mathrm{a} \\
(20)\end{array}$ & $\begin{array}{l}5.76 \mathrm{~d} \\
(81.7)\end{array}$ & $\begin{array}{l}21.7 \mathrm{bc} \\
(75)\end{array}$ & $\begin{array}{l}30.7 c \\
(75.4)\end{array}$ & $\begin{array}{l}0.42 \mathrm{c} \\
(2.4)\end{array}$ \\
\hline $\begin{array}{l}\text { B. amyloliquefacian } \\
\text { (MAS526) }\end{array}$ & $\begin{array}{l}7.3 \mathrm{a} \\
(46)\end{array}$ & $\begin{array}{c}13.1 \mathrm{a} \\
(138.2)\end{array}$ & $\begin{array}{l}50.2 \mathrm{a} \\
(256)\end{array}$ & $\begin{array}{l}17.2 \mathrm{~b} \\
(237.3)\end{array}$ & $\begin{array}{l}3.0 \mathrm{a} \\
(20)\end{array}$ & $\begin{array}{l}10.07 \mathrm{c} \\
(217.7)\end{array}$ & $\begin{array}{l}34.7 a b \\
(179.8)\end{array}$ & $\begin{array}{l}51.9 \mathrm{ab} \\
(196.6)\end{array}$ & $\begin{array}{l}0.50 \mathrm{bc} \\
(22)\end{array}$ \\
\hline B. insolitus (MAS10) & $\begin{array}{l}6.7 a \\
(34)\end{array}$ & $\begin{array}{l}10.9 b \\
(98.2)\end{array}$ & $\begin{array}{l}37.0 \mathrm{~b} \\
(162.4)\end{array}$ & $\begin{array}{l}18.3 \mathrm{~b} \\
(258.8)\end{array}$ & $\begin{array}{l}3.0 \mathrm{a} \\
(20)\end{array}$ & $\begin{array}{l}10.11 \mathrm{c} \\
(218.9)\end{array}$ & $\begin{array}{l}28.2 b \\
(127.4)\end{array}$ & $\begin{array}{l}46.5 b \\
(165.7)\end{array}$ & $\begin{array}{l}0.65 a \\
(58.5)\end{array}$ \\
\hline B. insolitus (MAS26) & $\begin{array}{l}6.5 a \\
(30)\end{array}$ & $\begin{array}{l}12.2 \mathrm{ab} \\
(121.8)\end{array}$ & $\begin{array}{l}41.5 \mathrm{ab} \\
(194.3)\end{array}$ & $\begin{array}{l}24.5 \mathrm{a} \\
(380.4)\end{array}$ & $\begin{array}{l}3.0 \mathrm{a} \\
(20)\end{array}$ & $\begin{array}{l}10.55 b \\
(232.8)\end{array}$ & $\begin{array}{l}34.2 \mathrm{ab} \\
(175.8)\end{array}$ & $\begin{array}{c}58.7 \mathrm{a} \\
(235.4)\end{array}$ & $\begin{array}{l}0.72 \mathrm{a} \\
(75.6)\end{array}$ \\
\hline $\begin{array}{l}\text { Microbacterium sp. } \\
\text { (MAS133) }\end{array}$ & $\begin{array}{l}7.2 a \\
(44)\end{array}$ & $\begin{array}{l}14.7 \mathrm{a} \\
(167.3)\end{array}$ & $\begin{array}{l}47.1 \mathrm{a} \\
(234)\end{array}$ & $\begin{array}{l}22.7 \mathrm{a} \\
(345.1)\end{array}$ & $\begin{array}{l}3.0 \mathrm{a} \\
(20)\end{array}$ & $\begin{array}{l}11.51 \mathrm{a} \\
(263.1)\end{array}$ & $\begin{array}{l}40.3 a \\
(225)\end{array}$ & $\begin{array}{l}63.0 \mathrm{a} \\
(260)\end{array}$ & $\begin{array}{l}0.56 \mathrm{~b} \\
(36.6)\end{array}$ \\
\hline $\begin{array}{l}\text { P. syringae } \\
\text { (MAS129) }\end{array}$ & $\begin{array}{l}6.8 \mathrm{a} \\
(36)\end{array}$ & $\begin{array}{l}14.1 \mathrm{a} \\
(156.4)\end{array}$ & $\begin{array}{l}38.5 b \\
(173)\end{array}$ & $\begin{array}{l}21.8 \mathrm{ab} \\
(327.5)\end{array}$ & $\begin{array}{l}3.0 \mathrm{a} \\
(20)\end{array}$ & $\begin{array}{l}10.71 b \\
(237.9)\end{array}$ & $\begin{array}{l}37.2 \mathrm{a} \\
(200)\end{array}$ & $\begin{array}{c}59.0 \mathrm{a} \\
(237.1)\end{array}$ & $\begin{array}{l}0.59 a b \\
(43.9)\end{array}$ \\
\hline LSD $p<0.05$ & 1.06 & 1.24 & 4.71 & 3.8 & 0.243 & 0.307 & 5.1 & 7.3 & 0.11 \\
\hline$p<0.01$ & 1.42 & 1.67 & 6.32 & 5.1 & 0.326 & 0.412 & 6.8 & 11.2 & 0.15 \\
\hline
\end{tabular}

LSD = least significant difference; CFU = colony forming units; DW = dry weight; RS = rhizosheath

"Figures in a column followed by different letter(s) are significantly different by Duncan's multiple range test $(p<0.05)$.

${ }^{* *}$ Figures in parentheses represent \% increase over un-inoculated control.

Table 2: Soluble and insoluble soil saccharides content of RS, mass of RS, RS to root ratio (RS/RT), and the EPS-producing bacterial population densities of rhizoplane and RS fractions of the wheat plants un-inoculated and inoculated with EPSproducing bacteria

\begin{tabular}{|c|c|c|c|c|c|c|}
\hline \multirow[b]{2}{*}{ Bacterial strains } & \multicolumn{2}{|c|}{ RS soil saccharides } & \multirow[b]{2}{*}{ RS } & \multirow{2}{*}{$\begin{array}{l}\mathrm{RS} / \mathrm{RT} \\
\text { (mg/plant) }\end{array}$} & \multicolumn{2}{|c|}{ Bacteria/g DW ${ }^{\mathrm{a}}$} \\
\hline & Soluble & $\begin{array}{l}\text { Insoluble } \\
\text { ( } \mu \mathrm{g} / \text { plant })\end{array}$ & & & Rhizoplane & $\begin{array}{c}\mathrm{RS} \\
(\log \mathrm{CFU})\end{array}$ \\
\hline Control & $45 b^{b}$ & $299 e$ & $\begin{array}{l}128 \mathrm{e} \\
(34.6 \mathrm{a})^{\mathrm{c}}\end{array}$ & $25.1 \mathrm{e}$ & $6.95 c$ & $5.03 \mathrm{c}$ \\
\hline B. amyloliquefaciens (MAS4) & $49 b$ & 799d & $\begin{array}{l}306 \mathrm{~d} \\
(19.5 \mathrm{bc})\end{array}$ & $34.0 \mathrm{~d}$ & $8.05 b$ & 7.01a \\
\hline B. amyloliquefaciens (MAS526) & $92 a$ & $2242 c$ & $\begin{array}{l}833 c \\
(12.1 e)\end{array}$ & $48.4 \mathrm{ab}$ & $8.46 a$ & $6.23 b$ \\
\hline B. insolitus (MAS10) & $85 a$ & 1869c & $\begin{array}{l}769 c \\
(22.0 b)\end{array}$ & 42.0c & $8.32 \mathrm{a}$ & $6.53 a$ \\
\hline B. insolitus (MAS26) & $84 a$ & $3211 \mathrm{a}$ & $\begin{array}{l}1049 \mathrm{~b} \\
(15.5 \mathrm{~d})\end{array}$ & $42.8 \mathrm{c}$ & 8.31a & $6.29 \mathrm{ab}$ \\
\hline Microbacterium sp. (MAS133) & $49 b$ & $3428 a$ & $\begin{array}{l}1220 \mathrm{a} \\
(17.0 \mathrm{~cd})\end{array}$ & $53.7 \mathrm{a}$ & $8.60 a$ & $6.87 a$ \\
\hline P. syringae (MAS129) & $43 b$ & $2714 b$ & $\begin{array}{l}\text { 1073ab } \\
\text { (21.7b) }\end{array}$ & $49.2 \mathrm{a}$ & $8.54 a$ & $6.97 a$ \\
\hline LSD $p<0.05$ & 7.5 & 324.4 & $\begin{array}{l}114 \\
(2.5)\end{array}$ & 5.15 & 0.22 & 0.34 \\
\hline$p<0.01$ & 10.1 & 435.3 & $\begin{array}{l}152 \\
(3.3)\end{array}$ & 6.9 & 0.40 & 0.58 \\
\hline
\end{tabular}

${ }^{\mathrm{a}} \mathrm{DW}=$ dry weight. ${ }^{\mathrm{b}}$ Figures in a column followed by different letter(s) are significantly different by Duncan's multiple range test $(p<0.05)$. ' Figures in parentheses represent $\%$ moisture content 
M. Ashraf, et al.

Table 3: $\mathrm{Ca}^{2+}, \mathrm{Na}^{+}, \mathrm{K}^{+}$contents and $\mathrm{K}^{+} / \mathrm{Na}^{+}$ratios of RS, roots and shoot portions of the wheat plants un-inoculated and inoculated with EPS-producing bacteria

\begin{tabular}{|c|c|c|c|c|c|c|c|c|c|c|c|}
\hline & & $\mathrm{Ca}^{2+}$ & & & $\mathrm{Na}^{+}$ & & & $\mathrm{K}^{+}$ & & $\mathrm{K}^{+} / \mathrm{Na}^{+}$ & \\
\hline Bacterial strains & RS & Roots & Shoot & RS & $\begin{array}{l}\text { Root } \\
(\mu \mathrm{m}\end{array}$ & $\begin{array}{l}\text { Shoot } \\
\text { le/g DW }\end{array}$ & $\mathrm{RS}$ & Root & Shoot & Root & Shoot \\
\hline Control & $37.2 a^{b}$ & $78.2 a$ & $60.6 a$ & $134 a$ & $1245 a$ & $1752 a$ & $0.57 \mathrm{e}$ & $28.6 \mathrm{c}$ & $378 d$ & 0.023 & 0.216 \\
\hline $\begin{array}{l}\text { B. amyloliquefaciens } \\
\text { (MAS4) }\end{array}$ & 15.5b & 74.1ab & $37.2 \mathrm{de}$ & 143a & $1024 b$ & $896 \mathrm{~b}$ & $5.07 \mathrm{a}$ & $22.7 \mathrm{c}$ & 385d & 0.021 & 0.424 \\
\hline $\begin{array}{l}\text { B. amyloliquefaciens } \\
\text { (MAS526) }\end{array}$ & $8.2 \mathrm{c}$ & 71.9ab & $35.7 \mathrm{e}$ & 96bc & 661de & $432 d$ & $4.84 \mathrm{~b}$ & $24.2 \mathrm{c}$ & 390d & 0.037 & 0.904 \\
\hline $\begin{array}{l}\text { B. insolitus } \\
\text { (MAS10) }\end{array}$ & $7.2 \mathrm{c}$ & $67.5 b$ & $50.7 \mathrm{~b}$ & $104 \mathrm{~b}$ & $847 \mathrm{c}$ & 795bc & $2.58 c$ & 63.8a & 621ab & 0.076 & 0.781 \\
\hline $\begin{array}{l}\text { B. insolitus } \\
\text { (MAS26) }\end{array}$ & $7.4 \mathrm{c}$ & $50.3 \mathrm{c}$ & $46.3 \mathrm{bc}$ & $58 d$ & $562 e$ & 726bc & $2.16 \mathrm{~d}$ & $23.3 \mathrm{c}$ & 712a & 0.042 & 0.988 \\
\hline $\begin{array}{l}\text { Microbacterium sp. } \\
\text { (MAS133) }\end{array}$ & $7.3 \mathrm{c}$ & 51.6c & $42.4 \mathrm{~cd}$ & $84 c$ & 788cd & $658 c$ & $2.78 c$ & $27.7 \mathrm{c}$ & 461cd & 0.035 & 0.702 \\
\hline $\begin{array}{l}\text { P. syringae } \\
\text { (MAS129) }\end{array}$ & 5.3d & $36.6 \mathrm{~d}$ & $35.3 \mathrm{e}$ & 105b & 614e & 798bc & $2.19 d$ & $52.8 \mathrm{~b}$ & 561bc & 0.087 & 0.792 \\
\hline LSD $p<0.0$ & .07 & 7.12 & 4.72 & 8.8 & 108.5 & 139.8 & 0.264 & 5.93 & 76 & 0.008 & 0.206 \\
\hline$p<0.01$ & 1.44 & 9.55 & 6.33 & 11.9 & 146.6 & 187.6 & 0.345 & 7.95 & 102.8 & 0.009 & 0.21 \\
\hline
\end{tabular}

${ }^{\mathrm{a}} \mathrm{DW}=$ dry weight. ${ }^{\mathrm{b}}$ Figures in a column followed by different letter(s) are significantly different by Duncan's multiple range test $(p<0.05)$

Table 4: Coefficients of correlation (r) of different root growth parameters with insoluble soil saccharides (Sacch.) and dry mass of RS, and $\mathrm{Na}^{+}, \mathrm{K}^{+}$contents of the RS, roots and the whole plant of wheat (T. aestivum) inoculated with EPSproducing bacteria and grown in a salt-affected soil

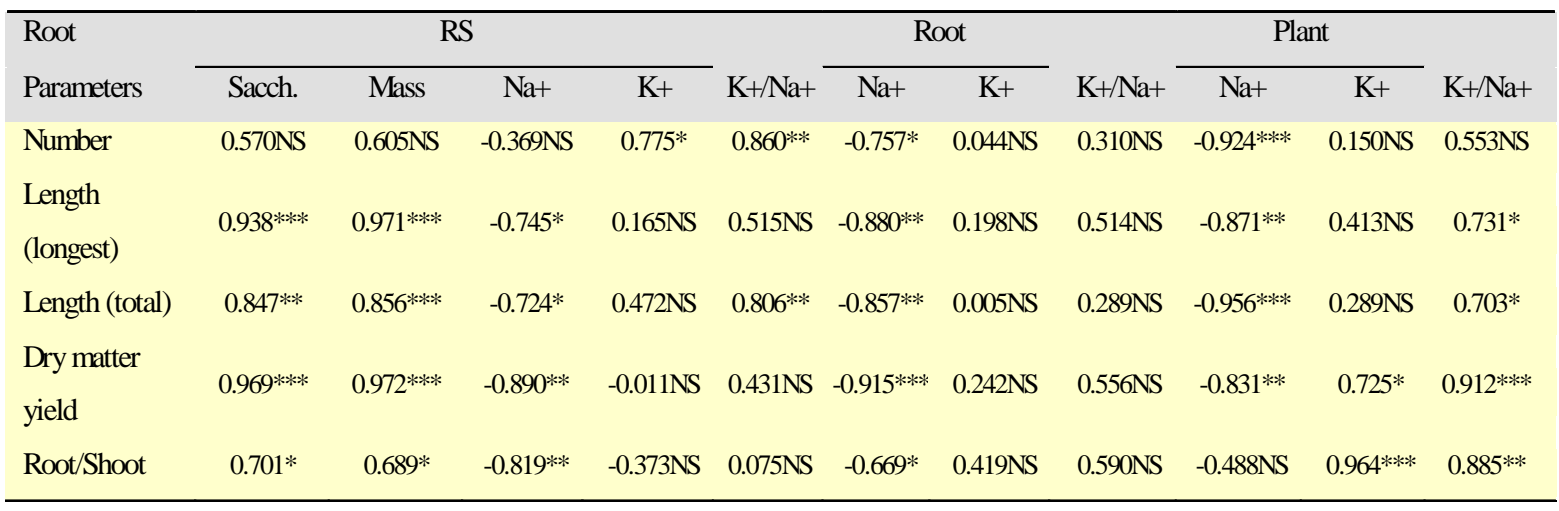

$*$, **, ***, Significant at $p>0.05, p>0.01$ and $p>0.001$ for $\mathrm{n}=7$, respectively; NS $=$ Non Significant

${ }^{\circ} \mathrm{C} / 21^{\circ} \mathrm{C}$ and an $8 \mathrm{~h}$ light period (450 $\mu$ moles photons $\left.\mathrm{m}^{-2} \mathrm{sec}^{-1}\right)$. The moisture content of the soil was maintained at $60 \%$ WHC (water holding capacity) by loss in weight method throughout the experiment.

After a 25-d growth, soil was knocked out of the pots, and plants recovered with intact roots were stirred for 1 min on a vibrating arm shaker to remove the soil loosely adhered to the roots (Gouzou, et al. 1993). The soil more tightly bound to the roots (hereafter rhizosheath soil, RS) was recovered by washing with distilled water. The experiment was run in six replica pots and the shoots, roots, and RSs of 4 plants of each replicate pot were pooled before analyses. Potassium, $\mathrm{Na}^{+}$, and $\mathrm{Ca}^{2+}$ contents in plant tissues (acid digests) and in RSs (1:1 soil:water extracts) were determined by flame-photometry (Anonymous, 1980). Saccharides (as glucose equivalents) in the RS were measured by phenol-sulphuric acid method (Šafařík and Šantrůčková, 1992). Water-insoluble saccharides and $\mathrm{Na}^{+}$in the RS were determined from the air-dried residual soil obtained after filtering the RS-water suspension. The population density of EPS-producing bacteria on 
the rhizoplane and in the RS was determined by total viable plate count method using modified RCV-sucrose medium. Soil moisture content of the RS was determined by infrared thermobalance (Thermored, Orma, Italy). The dry matter yields of root and shoot portions of the plants were recorded after drying at 70 ${ }^{\circ} \mathrm{C}$ for $72 \mathrm{~h}$ while other root growth parameters were determined manually just after recovering the plants from the soil. Results are reported as means of six replicate pots. The significance between treatments was determined by ANOVA using PC package CoStat (CoHart Software, Berkeley, USA).

\section{RESULTS}

EPS-producing bacterial inoculation of roots resulted in significant $(p<0.01)$ increase in number of primary (seminal) roots (36-46\%), longest root length (42$167 \%)$, total root length (103-256\%) and dry matter yield of roots (77-380\%) plant ${ }^{-1}$ of the wheat plants grown in the salt-affected soil (Table 1). The extent of increase in root growth parameters varied with the inoculated bacterial strains. The minimum (77\%) and maximum (380\%) values of increase in root dry matter were observed in MAS4 (B. amyloliquefaciens) and MAS26 (B. insolitus) inoculated plants, respectively. Although both the number of leaves and total leaf area plant ${ }^{-1}$ were also increased due to EPS-producing bacterial inoculation, the leaf area had a highly significant correlation with shoot dry matter yield ( $r=0.963$ $p<0.001$ ). An increase in root/shoot ratio (Table 1 ) indicated that the effect of inoculation was more on growth of roots than shoot of the inoculated plants. Besides root and shoot growth parameters, the stimulatory effect of inoculation was much more pronounced on mass of RS, which showed a 139-853\% increase over un-inoculated control ( $p<0.01$, Table 2$)$. With most of the strains, inoculation increased the population density of EPS-producing bacteria, particularly on the rhizoplane $(p<0.05$, Table 2$)$. The population densities of EPS-producing bacteria on the rhizoplane, but not that of the RS, were significantly correlated with the mass of RS $(r=0.859, p<0.01)$, and the dry matter yields of roots $(r=0.842, p<0.01)$ and shoot $(r=0.930, p<0.001)$. Comparing different strains, inoculation with MAS4 showed least effects on yield parameters. With exception to MAS4, all the bacterial strains increased the RS/Root mass ratio compared to un-inoculated ( $p<0.01$, Table 2$)$, and this ratio correlated with the content of water-insoluble saccharides in the
RS ( $r=0.866, p<0.01)$. The EPS-producing bacteria also varied in influencing $\mathrm{Ca}^{2+}, \mathrm{K}^{+}$and $\mathrm{Na}^{+}$levels, both in $\mathrm{RS}$ and in the plant components (Table 3 ). The concentration of $\mathrm{Ca}^{2+}$ in the RS of inoculated plants was always lower (58-86\% decrease, $p<0.01$ ). The root $\mathrm{Ca}^{2+}$ level was not affected by inoculation with MAS4 and MAS526, but it was $14-53 \%$ lower with other strains as compared to un-inoculated $(p<0.01)$. The $\mathrm{K}^{+}$ concentration in the RS of inoculated plants was 268$789 \%$ higher than that of un-inoculated $(p<0.01)$. However, $\mathrm{K}^{+}$level in the roots was either not affected by inoculation, or showed a $85 \%$ and $124 \%$ increase with MAS129 and MAS10, respectively $(p<0.01)$. Shoot $\mathrm{K}^{+}$level also increased due to inoculation (48-88\% increase, $p<0.01$ ), except that MAS4, MAS526, and MAS133 had no significant effect. The RS of inoculated plants showed lower $\mathrm{Na}^{+}$concentrations than that of un-inoculated with exception to MAS4 treatment, which possessed the $\mathrm{Na}^{+}$level similar to that of uninoculated ( $p<0.01$, Table 3 ). Inoculation also decreased the root $\mathrm{Na}^{+}$concentration $(p<0.01)$, the effect being least pronounced with MAS4 (only 18\% decrease) compared to other strains (32-55\% decrease). All the strains also significantly decreased the $\mathrm{Na}^{+}$level in the shoots (49-75\% decrease over un-inoculated, $p<0.01$ ). It might appear that the observed lower $\mathrm{Na}^{+}$ levels in the RS of inoculated than un-inoculated plants were a depletion effect, i.e. the inoculated plants due to their higher biomass extracted more $\mathrm{Na}^{+}$from $\mathrm{RS}$. However, this was not true. Due to lower moisture content in the RS of inoculated plants, $\mathrm{Na}^{+}$ concentration in the solution phase of RS (expressed as $\mathrm{m} M$ ) was generally much higher in inoculated than un-inoculated plants. Roots of un-inoculated plants possessed $\mathrm{Na}^{+}$level similar to that in the RS while inoculated plants consistently showed much lower $\mathrm{Na}^{+}$ concentration than in their respective RS. With exception to MAS4, roots of inoculated plants maintained a higher $\mathrm{K}^{+} / \mathrm{Na}^{+}$ratio (Table 3 ). This was apparently due to the restricted transport of $\mathrm{Na}^{+}$from RS to roots of inoculated plants. Besides, relatively higher $\mathrm{K}^{+}$concentration in roots of the plants treated with MAS10 and MAS129 also contributed to higher $\mathrm{K}^{+} / \mathrm{Na}^{+}$ratios. Probably due to the preferential transport of $\mathrm{K}^{+}$over $\mathrm{Na}^{+}$from roots to shoots, the latter always maintained much higher $\mathrm{K}^{+} / \mathrm{Na}^{+}$ratio than roots. Moreover, $\mathrm{K}^{+} / \mathrm{Na}^{+}$ratio of shoots of inoculated plants differed significantly from un-inoculated $(p<0.01)$, again MAS4 showing the least effect. 


\section{DISCUSSION AND CONCLUSION}

Lack of a good correlation of all the root growth parameters with $\mathrm{K}^{+}$contents and $\mathrm{K}^{+} / \mathrm{Na}^{+}$ratios of $\mathrm{RS}$, root and the plant (Table 4) and a weak correlation of all the root growth parameters with $\mathrm{Ca}^{2+}$ contents of root and the plant (data not shown) exhibited that growth of the roots could not be associated with those cations. Results of another similar experiment conducted with the strains used in our earlier study (Ashraf, et al., 2004) also showed comparable trends except a significant correlation $(r=0.898, p<0.01)$ of the number of primary (seminal) roots with $\mathrm{K}^{+}$content of the plant (unpublished data). Although role of the cations $\mathrm{K}^{+}, \mathrm{Ca}^{2+}$ and the $\mathrm{K}^{+} / \mathrm{Na}^{+}$ratio in maintaining osmotic potential of the plants against rootzone salinity is well established (Song and Fujiyama, 1996), researchers have observed both positive and no effect of cation feeding on growth of the plants (Jeschke and Wolf, 1988). A negative correlation of $\mathrm{Na}^{+}$contents of RS, root and the plant with the root growth parameters (Table 4), however, indicated a positive impact of decrease in $\mathrm{Na}^{+}$uptake on growth of roots and shoot of the wheat plants. Despite the fact that growth of both roots and shoot was improved due to a reduced $\mathrm{Na}^{+}$uptake, a higher root/shoot ratio predicted that the effect was more on growth of roots than shoot of the plants. A higher growth of roots than shoot of the inoculated plants and a highly significant positive correlation of all the root growth parameters (except number of seminal roots) with dry mass and water insoluble soil saccharides content of the RS (Table 4) indicated that influence of the RS factors on growth of roots was more prominent and stronger than a decrease in $\mathrm{Na}^{+}$uptake by inoculated wheat plants. Since the EPS-producing bacteria were isolated from the saltaffected soils and were adapted to the salts stress (Miller, et al., 1996), their inherent salt tolerant capability helped the plants to withstand initial effect of osmotic stress (Munns, 2002). Moreover, a higher EPS-producing bacterial population harboured initially on roots of the inoculated than un-inoculated plants was enable to stimulate and enhance the extent of the root exudates (Tisdall, 1994; Miller, et al., 1996; Wittenmayer and Merbach, 2005). Thus in consequence to intensive release of the plant root exudates in the rhizosphere, the EPS-producing bacterial population was increased further and the extent of EPS synthesis was fostered. A higher insoluble soil saccharides content of RS of the inoculated than un-inoculated wheat plants was thus indication of an enhanced EPS synthesis activity in the rootzone. An increased mass of soil aggregated around roots of the inoculated than un-inoculated wheat plants and a highly significant positive correlation $(r=0.866, p<0.01)$ of water insoluble soil saccharides with RS/root ratio signified the implication of the bacterial EPS in aggregating soil around roots over other soil microbial secretions or plant mucilages (Watt, et al., 1993; Alami, et al., 2000; Bezzate, et al., 2000). Origin of the EPS, however, could not be ascribed specifically to the inoculated EPSproducing bacterial isolates since the chemical structure and quantity of the individual component of the soil saccharides were not determined.

A decline in soil moisture content of RSs of the inoculated than un-inoculated wheat plants could be attributed to a higher loss of water from rhizosphere soil. A higher water uptake by upper parts of the plants was considered responsible for decrease in rhizospheric water content of the wheat plants inoculated with Azosprillum sp. (Bashan, et al. 2000). It was concluded that in consequence to Azosprillum sp. inoculation, an improved biomass yield of shoot portion of the inoculated wheat plants resulted in a higher uptake of water from the soil which decreased the negative effects of the salts stress on growth of the plants. No doubt an improved RS permeability as a result of a higher soil aggregation around roots (Alami, et al. 2000), a decreased soluble salts content of the rhizosphere soil resulted from binding of the excessive soluble cations into the rhizosheath-root complex through EPS-cation-soil bridging (Marshall, 1975; Morel, et al., 1991) and a positive water potential of the bacterial EPS (Miller, et al., 1996) content of the RS could all support to the plants to draw a greater quantity of water from the rhizosphere soil. However, as the increase in growth and biomass yield of the plants grown in the stressed environments follow the decrease in stress on growth (Munns, 2002), a higher soil water uptake by a well grown shoot portion of the plants could not be solely responsible for improved growth of the wheat plants inoculated with the EPS-producing bacterial isolates. It could be envisaged that other RS factors including the mechanical impedance (the axial root pressure exerted per unit area), gaseous and moisture contents of the RS-root complex have also influenced growth and biomass yield of the inoculated wheat plants. A higher mechanical impedance on roots could be exerted by an increased mass of the RS under 
dry conditions, an increased root biomass and the rhizobacterial population could enhance roots and soil microbial respiration that in turn could influence rhizosphere gaseous $\left(\mathrm{CO}_{2}, \mathrm{O}_{2}\right)$ content, while flooding of the RS-root complex during irrigation periods could create an anoxic environment in the rootzone. These all RS factors have been reported to control and regulate, through stimulating synthesis and release of the stress phytohormones in the rhizosphere, growth and functioning of roots of the plants (Mohr and Schopfer, 1996; Clarke et al., 2003; Kuzyakov and Larionova, 2005; Wittenmayer and Merbach, 2005). It was thus considered that growth of roots of the wheat plants inoculated with the EPS-producing bacterial isolates was increased due to stress phytohormones activity. Nonetheless, a restricted $\mathrm{Na}^{+}$uptake and the cellular water contents of the plants maintained by a higher soil water uptake diluted out and mitigated the negative effects of salts stress (Bacillio, et al., 2004) but a higher soil nutrient and water availability to plants by a prolific root biomass would also have contributed to biomass yield of the inoculated wheat plants. In uninoculated control, however, because of lack of RSs, a lower EPS-producing bacterial population density harboured initially on the roots and a lower soil microbial activities, a bigger part of the roots was uncovered and devoid of RS. This higher uncovered root area thus was prone to a higher influx of $\mathrm{Na}^{+}$in the plant (Ashraf, et al., 2004). This increased influx of $\mathrm{Na}^{+}$ through uncovered root area suppressed the activity of the plant growth promoting phytohormones (Munns, 2002) and resulted in a decrease in growth of roots and in consequence a decrease in growth of shoot of the plants.

It could be concluded that root inoculation of the wheat plants with EPS-producing bacterial isolates native to the salt-affected soils through increasing extent of soil aggregation around roots provided a 'blanket salt-tolerant cover' to the roots. In consequence, a combination of biotic and abiotic RSs factors (Clarke, et al., 2003) through regulating activities of the stress phytohormones promoted and controlled growth of roots of the inoculated wheat plants grown under salts stress conditions. A well proliferated roots in response to EPS-producing bacterial inoculation not only enabled the plants to withstand the initial effects of salts and the osmotic stresses but it also benefited the inoculated plants in terms of a better exploitation of the soil nutrients and through providing an increased extent of rhizodeposits in the soil for gearing up of the soil microbial activities. The decrease in the impact of salts and osmotic stresses on growth and functioning of the roots consequently improved growth and biomass yield of the wheat plants inoculated with the EPS-producing bacterial isolates. So inoculation of the plants with selected EPS-producing bacteria may serve as a useful tool for ameliorating salinity stress on growth of the crop plants and to improve fertility as well as productivity of the salt-affected soils.

\section{ACKNOWLEDGMENTS}

This research work was partly supported by an International Foundation for Science (IFS), Sweden and COMSTECH, Islamabad, under research grant No. C/ 3015. Authors also gratefully acknowledge Dr. Theirry Heulin, DSV-DEVM, CEA, Cadarache, France, for providing laboratory facilities for isolation and identification of the EPS-producing bacteria, Dr. Tariq Mahmood, the Principal Scientist, for his valuable comments and suggestions for the manuscript and Mr. Mahmmood-ul-Hassan, the Scientific Assistant, NIAB, Faisalabad, Pakistan, for providing technical assistance for the research study.

\section{REFERENCES}

Alami, Y., Achouak, W., Marol, C. and Heulin, T., (2000). Rhizosphere soil aggregation and plant growth promotion of sunflowers by an exopolysaccharide-producing Rhizobium sp. strain isolated from sunflower roots. Appl. Environ. Microbiol., 66, 3393-3398.

Amellal, N., Burtin, G., Bartoli, F. and Heulin, T., (1998). Colonization of wheat roots by EPS-producing Pantoea agglomerans and its effect on rhizosphere soil aggregation. Appl. Environ. Microbiol., 64, 3740-3747.

Anonymous, (1980). Standard methods of analysis for soil, plant tissue, water and fertilizer. Philippine Council for Agriculture and Resource Research, Los Baños, Laguna, 194.

Ashraf, M., Berge, O., Azam, F. and Heulin, T., (1999). Bacterial exo-polysaccharides and productivity of the salt affected soils: I. Diversity of exo-polysaccharide producing bacteria from the rhizosphere of wheat (Triticum aestivum L.) grown in normal and saline Pakistani soils. Pak J Biol Sci., 2, 201206.

Ashraf, M., Hasnain, S., Berge, O. and Mahmood, T., (2004). Inoculating wheat seedlings with exo-polysaccahrides producing bacteria restricts sodium uptake and stimulates plant growth under salt-stress. Biol. Fertil. Soils., 40, 157162.

Atkinson, D., (2000). Root characteristics: why and what to measure. In: Root Methods: A handbook. Smit, A. L., Bengough, A. G., Engels, C., van Noordwijk, M., Pellerin, S. and van de Geijn, S. C. (Eds.). Springer-Verlag, Berlin, Heidelberg, Germany. 1-32. 
Bacillio, M., Rodriguez, H., Moreno, M., Hernandez, J. P. and Bashan, Y., (2004). Mitigation of salt stress in wheat seedlings by a gfp-tagged Azospirillum lipoferum. Biol. Fertil. Soils., 40, 188-193.

Bashan, Y., Moreno, M. and Troyo, E., (2000). Growth promotion of the seawater-irrigated oilseed halophyte Salicornia bigelovi inoculated with mangrove rhizosphere bacteria and halotolerant Azospirillum spp. Biol. Fertil. Soils., 32, 265-272.

Bezzate, S., Aymerich, S., Chambert, R., Czarnes, S., Berge, O. and Heulin, T., (2000). Disruption of the Paenibacillus polymyxa levansucrase gene impairs its ability to aggregate soil in the wheat rhizosphere. Environ. Microbiol., 2, 333342.

Chenu, C. and Guerif, J., (1991). Mechanical strength of clay minerals as influenced by an absorbed polysaccharide. Soil Sci. Soc. Am. J., 55, 1076-1080

Clarke, L. J., Whalley, W. R. and Barraclough, P. B., (2003). How do roots penetrate strong soil? Plant Soil, 255, 93104.

Czarnes, S., Hallett, P. D., Bengough, A. G. and Young I. M., (2000). Root- and microbial-derived mucilages affect soil structure and water transport. Eur. J. Soil Sci., 51, 435-443.

Gouzou, L., Burtin, G., Philippy, R., Bartoli, F. and Heulin, T., (1993). Effect of inoculation with Bacillus polymyxa on soil aggregation in the wheat rhizosphere: preliminary examination. Geoderma, 56, 479-490.

Jeschke, W. D. and Wolf, O., (1988). External potassium is not required for root growth in saline conditions: Experiments with Ricinus communis L. Growth in a reciprocal split-root system. J. Exp. Bot., 39, 1149-1167.

Kuzyakov, Y. and Larionova, A. A., (2005). Root and rhizomicrobial respiration: A review of approaches to estimate respiration by autotrophic and heterotrophic organisms in soil. J. Plant Nutr. Soil Sci., 168, 503-520.

Marshall, K. C., (1975). Clay mineralogy in relation to survival of soil bacteria. Anuu. Rev. Phytopathol., 13, 357-373.

McCully, M. E. and Canny, M. J., (1988). Pathways and processes of water and nutrient movement in roots. Plant Soil, 111, 159-170.

Miller, K. J. and Wood J. M., (1996). Osmoadoptation by rhizosphere bacteria. Annu. Rev. Microbiol., 50, 101-136.

Mohr, H. and Schopfer, P., (1996). Physiology of hormone action. In: Plant Physiology. Lawlor G., and Lawlor D. W. (transl. eds.). Springer-Verlag, Berlin - Heidelberg, Germany, 383-408.
Morel, J. L., Habib, L., Plantureux, S. and Guckert, A., (1991). Influence of maize root mucilage on soil aggregate stability. Plant Soil, 136, 111-119.

Munns, R., (2002). Comparative physiology of salt and water stress. Plant Cell Environ., 25, 239-250.

Nannipieri, P., Ascher, J., Ceccherini, M. T., Landi, L. Pietramellara, G. and Renella, G., (2003). Microbial diversity and soil functions. Europ. J. Soil Sci., 54, 655-670.

Rengasamy, P., Chittleborough, D. and Helyar, K., (2003). Rootzone constraints and plant-based solutions for dryland salinity. Plant Soil, 257, 249-260.

Šafaøík,W. O. and Šantrùèková, H., (1992). Direct determination of total soil carbohydrate content. Plant Soil, 143, 109-114.

Shen, W., Gomez-Cadenas, A., Routly, E. L., Ho, T-H. D., Simonds, J. A. and Gulick, P. J., (2001). The salt stress inducible protein kinase gene, Esi47, from the salt-tolerant wheatgrass Lophopyrum elongatum is involved in plant hormone signalling. Plant Physiol., 78, 1429-1441.

Song, J. Q. and Fujiyama, H., (1996). Ameliorative effects of potassium on rice and tomato subjected to sodium salinization. Soil Sci. Plant Nutr., 42, 493-501.

Tisdall, J. M., (1994). Possible role of soil micro-organisms in aggregation of soils. Plant Soil, 159, 115-121.

Vanhaverbeke, C., Heyraud, A. and Mazeau, K., (2003). Conformational analysis of the exo-polysaccharide from Burkholderia caribensis strain MWAP71: Impact on the interaction with soils. Biopolymers., 69, 480-497.

Watt, M., McCully, M. E. and Canny M. J., (1994). Formation and stabilization of rhizosheaths of Zea mays L. Plant Physiol., 106, 179-186.

Watt, M., McCully, M. E. and Jeffree, C. E., (1993). Plant and bacterial mucilages of maize rhizosphere: comparison of their soil binding properties and histochemistry in a model system. Plant Soil, 151, 151-165.

Wittenmayer, L. and Merbach, W., (2005). Plant responses to drought and phosphorus deficiency: Contribution of phytohormones in root related processes. J. Plant Nutr. Soil Sci., 168, 531-540. 


\section{AUTHOR(S) BIOSKETCHES}

Ashraf, M., M.Sc., M.S., is working as senior scientist in Salinity and Environmental Management Division (SEMD), Nuclear Institute for Agriculture \& Biology (NIAB), P.O. Box 128, Jhang Road, Faisalabad 38000, Pakistan, and is a Ph.D. research scholar in the Department of Botany at the University of the Punjab, Lahore, Pakistan. E-mail: botany_malik@yahoo.com

Hasnain, Sh., Ph.D., is a professor in the Department of Botany, University of the Punjab, Quaide-Azam Campus, Lahore 54590, Pakistan. E-mail: genetic@brain.net.pk

Berge, O., Ph.D., is senior researcher in the Department of Laboratoire d'Ecologie Microbienne de la Rhizosphère (LEMiR), UMR 163 CNRS-CEA, Commissariat á l' énergie atomique (CEA), Cadarache, F-13 108 Saint Paul lez-Durance, France. E-mail: berge@dsvsud.cea.fr

\section{This article should be referenced as follows:}

Ashraf, M., Hasnain, S.and Berge, O., (2006). Effect of exo-polysaccharides (EPS) producing bacterial inoculation on growth of roots of wheat (Triticum aestivum L.) plants grown in a saltaffected soil. Int. J. Environ. Sci. Tech., 3 (1), 43-51. 